\title{
Rediscovery of Emotion Coaching
}

ZHAO BO

\begin{abstract}
The theory of Emotion Coaching was put forward by Feng Menglong in Late-Ming Dynasty. Since Mid-Ming, the cognition of Ch'ing (emotion) has gone through three phases: rediscovery, development, and explanation on the level of the mind. Deeply influenced by Yangming, the theory of Emotion Coaching focuses neither on Ch' ing (emotion) nor on $\mathrm{Li}$ (justice) but the balance of the two. That "Ch'ing (emotion) is the basis of $\mathrm{Li}$ (justice) and $\mathrm{Li}$ (justice) is the criterion of Ch'ing (emotion)" is taken as the tenet of the theory, which means that $C h$ 'ing (emotion) gives rise to moral behaviour and $L i$ (justice) is the standard. The book The History of Ch'ing (《情史》) fully reflects the theory. Separating emotion and desire, $L i$ (justice) is different from $L i$ (rite). The former is based on human nature. Justice and destiny are the two important principles, rather than the political purposes which infuse the latter. The theory of Emotion Coaching is also reflected in the collection of short novels San Yen (“三言”). In the novel, the details of emotion are fantastic, trying to make sense of emotional varieties. Affective and wanton behaviour are shown differently in order to illustrate the discrepancy between emotion and desire. Justice and destiny are also emphasized. Chiang Hsingge Regained His Pearl Shirt (《蒋兴 哥重会珍珠衫) serves as an example here.
\end{abstract}

Keywords: Ch'ing; Li; Emotion Coaching; Feng Menglong

Since Mid-Ming Dynasty, Chinese society had gone through great changes. Commodity economy development, population mobility and ideological innovation have thrown the traditional ethical structure into disorder. In the past, $L i$ (rite) of San Gang, meaning that the ruler guides the subject, the father guides the son and the husband guides the wife, had propped society up, from the nobleman to the commoner. Social transformation now called for a new ethical standard, the restructuring of the relations between $\mathrm{Ch}^{\prime}$ ing (emotion), $L i$ (justice) and $L i$ (rite). Emotion Coaching (情教) was formulated by Feng Menglong (冯梦龙1574-1646) against such a background. Several scholars thought that $\mathrm{Ch}^{\prime}$ ing (emotion) was the substitute for $\mathrm{Li}$ (rite), for example Fu Ch'engchou (傅承洲,Fu Ch'engchou 2003) and Fang Sheng (方胜, Fang Sheng 1985). Several scholars said that Feng Menglong had also preached the traditional morality, and even made it steadier. Ho Yüehling (何悦玲, Ho 
Yüehling 2004) and Nie Fusheng (聂付生, Nie Fusheng 2002) focused on the relationship between $C^{\prime}$ 'ing (emotion) and $\mathrm{Li}$ (justice). Nie Fusheng said that Ch'ing is the basis of the feudal ethical code, and that the feudal ethical code is the internalization of Ch'ing (Nie Fusheng 2002: 82). All the viewpoints above are sensible, but not that accurate and also need a further statement. Emotion Coaching enquires into love between men and women, to show the dishonesty of the feudal ethical code (Feng Menglong 2007: 1). Meanwhile, it pursues justice and sensibility, which arose after Yangming's thought.

\section{The Relationship between Ch'ing (emotion) and $L i$ (justice)}

Since Mencius, Hsin (heart) has become an important conception in Chinese philosophy, and its connotation varies in different periods. Shao Yung (邵庸 1011-1077) in Earlier Sung Dynasty (960-1127) said that Hsin (heart) is Tai Chi (Shao Yung: vol. 8). Chang Tsai (张载1020-1077) asserted that Hsin (heart) contains Ch'ing (emotion) and Hsing (性) (Chang Tsai: vol. 14). Ch'eng Hao (程影1032-1085) emphasized that Li (justice) and Hsin (heart) are the same (Ch'eng Hao: vol. 5). Ch'eng Yi (程烦1033-1107) said that Hsin (heart) is Hsing (性). Reflected in nature, it is Ming (fate). And reflected in the human beings, it is Hsing (性) (Ch'eng Yi: vol. 18).

Chu His (朱喜1130-1200) epitomized the thought of Sung neoConfucianism. According to his theory, Hsin (heart) holds all the Li (justice) in the universe (Chu His 1986: vol. 9). Hsin (heart) contains Ch'ing (emotion) and Hsing (性) (Chu His 1986: vol. 6). Chu Hsi made a distinction between Man Heart (人心) and Tao Heart (道心). Tao Heart (道心) accords with justice. Hsing (性), reflecting Tao Heart (道心), is the Li (justice) existing in Hsin (heart), and it is static without evil (Chu His1986: vol. 5). Man Heart (人心) is reflected by emotions and desire (Chu His 1986: preface). Ch'ing (emotion) is the movement of $\mathrm{Hsin}$ (heart), with the separation of good and evil (Chu His 1986: vol. 5). Hsing (性) is the body and it is metaphysical. Ch'ing (emotion) is its function and it is physical (Chu His 1986: vol. 15). There is a saying in Shangshu (《尚书》) that Man Heart is dangerous, while Tao Heart is refined. Hence in the view of Chu His that Tao Heart (道心) should master Man Heart (人心), which is akin to the relationship of the rudder and the boat (Chu Hsi 1986: preface). That is to say that Hsing (性) and Li (justic) should govern Ch'ing (emotion). Thus, making a thorough inquiry into things outside the self is emphasized.

Wang Yangming (王阳明1472-1529) noticed a contradiction in Chu Hsi's theory, namely that $\mathrm{Hsin}$ (heart) and $\mathrm{Li}$ (justice) are separated in case of the distinction between Tao Heart (道心) and Man Heart(人心) (Wang 
$\mathrm{ZHAO}$

Yangming 2012: vol. 2). It would lead to hypocrisy when people only focus on the right behaviour though their hearts are not kind. Yangming stated that Hsin (heart) is Li (justice) (Wang Yangming 2012: vol. 3). Man Heart and justice are indivisible. There are no two hearts. Man Heart (人心) that is pure and upright can be taken as a Tao Heart (道心) as well, otherwise it is just Man Heart (人心). (Wang Yangming 2012: vol. 1) The difference between Tao Heart (道心) and Man Heart (人心) is whether the heart is governed by desire (Wang Yangming 2012: vol. 3).

Differently from Chu Hsi's thought that Hsing (性) reflects Tao Heart (道心) and Ch'ing (emotion) reflects Man Heart (人心), Yangming reckoned that Hsing (性) and $C h^{\prime}$ ing (emotion) are all reflections of the heart. Hsing (性) is the body and it is static (Wang Yangming 2012: vol. 1). Ch' 'ing (emotion) is the function and it is dynamic (Wang Yangming 2012: vol. 3). Seven human emotions - joy, anger, sorrow, fear, love, hate and desire - are permitted (Liu Tsungchou: vol. 1). The Ch'ing (emotion) of Tao Heart (道心) is pure, genuine and in accord with $\mathrm{Li}$ (justice) and Hsing (性), which is called Refined Emotion (至情) (Wang Bi: vol. 1). The Ch'ing (emotion) of Man Heart (人心) is Secular Emotion (俗情), mixed with desire (Wang Chi: vol. 13). Thus, emotion, especially Refined Emotion, can be taken to be in accord with Li (rite) (Wang Yangming 2012: vol. 5).

\section{The Logic of Emotion Coaching}

The cognition of Ch'ing (emotion) in Ming Dynasty was completed mainly through literature, and it had gone through three phases: rediscovery ( $\mathrm{Li}$ Tungyang李东阳1447-1516), development (Former and Latter Seven Masters ( 前后七子late $15^{\text {th }}$ - early $16^{\text {th }}$ century), and explanation on the level of the mind (Wang Yangming王阳明, Yuan Hungtao袁宏道1568-1610, T’ang Hsientsu 汤显祖1550-1616, T'u Long屠隆1544-1605, Feng Menglong冯梦龙15741646). Deeply influenced by Yangming, the theory of Emotion Coaching focused neither on $C h^{\prime}$ ing (emotion) nor on $L i$ (justice), but the balance of the two. The saying "Ch' ing (emotion) is the basis of Li (justice), and Li (justice) is the criterion of Ch'ing (emotion)" (Feng Menglong 2011: vol. 1) is taken as the tenet of the theory, which means that $C h^{\prime}$ ing (emotion) gives rise to moral behaviour and $\mathrm{Li}$ (justice) is the standard. Differently from Starting with Ch' ing (emotion) but restricted within $\mathrm{Li}$ (rite) (Maoshi: preface), Feng Menglong chose Li (justice) rather than $L i$ (rite), to avoid the confusion between $L i$ (justice) and $L i$ (rite) of San Gang. 
Emotion Coaching was based on Yangming's thought that Hsin (heart) is $\mathrm{Li}$ (justice) and Ch'ing (emotion) is the function of Hsin (heart) (Wang Yangming 2012: vol. 3). Thus, Ch'ing (emotion) is also a kind of reflection of $L i$ (justice). In the book The History of Emotions, which fully reflects the thought of Emotion Coaching, Feng Menglong introduced three features of Ch'ing (emotion). First, Ch'ing (emotion) will never end. Second, Ch'ing (emotion) is the root of creation. Third, $C h^{\prime}$ ing (emotion) connects all the things that are scattered. Spirit of Emotions (情灵), Transformation of Emotions (情化), Perception of Emotions (情感), and Trace of Emotions (情迹) are collected to illustrate it (Feng Menglong 2011: preface).

Influenced by Yangming, Feng Menglong distinguished people's emotions at three different levels. Confucius divided people into charitable people, common people and evil-doers (The Analects of Confucius, vol. 19, vol. 21). Wang Yangming followed this viewpoint. Ch' ing (emotion) of the sage is Refined Emotion (至情), and Ch'ing (emotion) of the common people and evil-doers is Secular Emotion (俗情). In his book The History of Emotions, Loyalty of Emotions(情贞),Fate of Emotions(情缘), Chivalry of Emotions (情侠), Detachment of Emotions (情豪), Sprouts of Emotions (情芽) are all Refined Emotions (至情). Sprouts of Emotions (情芽) pertain to the sage. Loyalty of Emotions(情贞) and Chivalry of Emotions (情侠) focus on emotions that are in accordance with righteousness (义) (Feng Menglong 2011: vol. 4). Fate of Emotions (情缘) and Detachment of Emotions (情 豪) illustrate the notion that emotions are restricted by fate (命), so that people should not be trapped. Righteousness (义) reflects the Li (justice) of behaviours. Fate (命) reflects the $L i$ (justice) of the Mandate of Heaven. Combined with the two elements, $L i$ (justice) of Feng Menglong accords with human nature. Women are equal to men, life is respected, there are fewer discrepancies between the important and the trivial, there is the celebration of human love, and moral behaviour is more genuine (Feng Menglong 2011: preface). Righteousness is different from rite, which means that men and women whose love is true should be matched, though that is contrary to the discipline of rite.

Obstinacy of Emotions (情疾), Regret of Emotions (情憾), Pornography of Emotions (情秽), Implications of Emotions (情累), Hatred of Emotions (情仇), and Retribution of Emotions (情报) in the book The History of Emotions are stories of common people and evil-doers. Obstinacy of Emotions (情痴) tells of people who indulge in love, so that they hurt themselves and ruin countries. There is a saying in the book that to counsel adamant people is good, with the exception of foolish lovers (Feng Menglong 2011: vol. 7). Regret of Emotions (情憾) tells about love denied a good outcome - talented girls without suitable mates and happy couples with one partner dying young. 
$\mathrm{ZHAO}$

Pornography of Emotions (情秽), Implications of Emotions (情累), and Hatred of Emotions (情仇) are emotions that are not righteous, such as the betrayal of love, jealousy and mercilessness in women, supplanting others in people's affections, coveting others men's wives, and dissolute women incurring disasters for their husbands, also crimes of passions. Retribution of Emotions (情报) illustrates the principle that good is rewarded with good and evil with evil. Here a remarkable distinction is made between love and desire. The emotions that are righteous and fatal are evidence of true love. Overflowing emotions are interpreted as desire that should be restricted. A saying by Feng Meng states that people would not be qualified for telling emotions without realizing Ch'ing (emotion) and Li (righteousness) (Feng Menglong 2011: vol. 18).

\section{The Application of Emotion Coaching}

In the collections of vernacular short stories San Yen (“三言”) by Feng Menglong, 40 of the 120 stories are on the subject of Ch'ing (emotion). For different genres detailed descriptions of emotions and statements of $\mathrm{Li}$ (justice) are provided, reflecting the application of Emotion Coaching. Chiang Hsingge Regained His Pearl Shirt (《蒋兴哥重会珍珠衫》, Feng Menglong 1991: vol. 1), the prelude to the collections, is typical.

In the story, Chiang Hsingge (蒋兴哥) and his wife Wang Sanch'iao (王三 巧) are the perfect match. The deep love between them is vivid. When Chiang Hsingge had to depart for Kuang Ch'ou on a business errand, he did not inform San Ch'iao until five days before leaving, in order not to hurt her. Hearing Chiang's decision, Sanch'iao wept ceaselessly and did not sleep at night, staying by her husband's side. Finally, she asked for Chiang's promise that he would return next year when willows sprout again. Chiang also cried when saying his farewells, and left his pearl shirt, handed down from his ancestors, as proof to his wife. During their separation, they missed each other deeply. Chiang did not look at other women. Sanch'iao did not go downstairs but looked out of the widow, looking forward to her husband's return, which unfortunately attracted Chen Talang's interest. Even after Sanch'iao's adultery, Chiang did not forget her, though they had divorced, and Sanch'iao tried her best to save Chiang when he was caught in a trap, by way of redemption. The scene of their reunion was so moving that they cried in each other's arms, grieved more than when losing their parents, without saying a word and forgetting courtesy.

In comparison, the relationship between Sanch'iao and her lover Chen Talang (陈大郎) is different. Though there are strong feelings, a lot of pornography is employed here which did not appear in the detailed descriptions 
of the relationship of Chiang Hsingge and Sanch'iao. The discrepancy shows the distinction between love and desire, which are called right emotions and wrong emotions. But the feelings of the right and wrong emotions are similar to each other, so Li (justice) is needed.

Righteousness in the story is stated at four points. First, Chiang and Wang are matched and love each other, thus there is no emotional reason for the woman to jeopardize her marriage. But Chiang should also take a little blame, for he had left his young wife at home alone for a long time, and did not come back soon enough. Second, Feng Menglong shows that Sanch'iao was completely tricked by Ch'en Talang and Wang P'o (王婆), so that Wang and Chiang's remarrying later is acceptable. Third, Sanch'iao's deep love for Chiang is proved by her longing, her refusal to go out and saving Chiang even when they had divorced. These are all remedies for her mistake. Fourth, though Sanch'iao could be forgiven, she finally became the concubine of Chiang, not his wife again, by way of retribution. Ch'en Talang and Wang P'o are punished at the end of the story. Chiang, because he values sensibility and loyalty, reunites his family and recovers his lost pearl shirt. There's a saying in the story that justice is around you, not far away (Feng Menglong 2011: vol. 16). Sun K'ait'I (孙楷第1898-1986) has said it is the most perfect story from which people can learn how to obtain knowledge by learning from it.

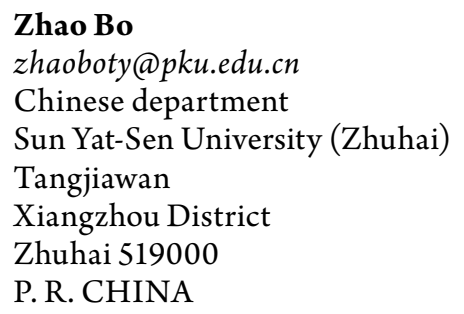

\section{References}

Chang Tsai, M. 2012. Books of Chang Tsai. Beijing: Chung Hua Book Co. (张载: 《张 载集》，中华书局2012年06月。)

Ch'eng Hao \& Ch'eng Yi, M.1981. Books of Ch'eng Hao and Ch'eng Yi. Beijing: Chung Hua Book Co. (程影、程弫: 《二程集》，中华书局 1981 年 07 月。)

Chu Hsi, M. 1986. The Analects of Chu Hsi. Beijing: Chung Hua Book Co. (朱喜: 《朱 子语类》, 中华书局 1986 年 03 月。)

Chu Hsi, M. 1983. Annotations of the Four Books. Beijing: Chung Hua Book Co. (朱喜: 《四书章句集注》，中华书局 1983 年 10 月。) 
Fang Sheng, J. 1985. Discussion of Feng Mong' s Emotion Coaching. - Literary Heritage, 4, 113-121.

Feng Menglong, M. 1991. Tales of Past and Present. Jiangsu: Jiangsu Ancient Publishing House Co. (冯梦龙: 《古今小说》, 江苏古籍出版社1991 年 09 月。)

Feng Menglong, M. 2011. The History of Emotions. Jiangsu: Jiangsu Phoenix Publishing House. (冯梦龙:《情史》, 凤凰出版社2011年10月。)

Feng Menglong, M. 2007. Collections of Folk Songs. Jiangsu: Jiangsu Phoenix Publishing House. (冯梦龙: 《山歌》, 凤凰出版社 2007 年 09 月。)

Fu Ch'engchou, J. 2003. Recomprehensions of Emotion Coaching. - Journal of MingQing Fiction Studies, 1, 40-43.

Ho Yüehling, D. 2004. The Analysis of Feng Menglong's View on Education Based on Emotion. Xi'an:Shan Xi Normal University.

Li Shuanghua, J. 2003. On the Thought of Emotional Education of Feng Meng-long. Journal of Liaoning Normal University (Social Science Edition), 1, 74-77.

Liu Tsungchou, Z. Books of Liu Tsungchou. Printed in Ch'ing Dynasty by Chengjen House. (刘宗周: 《刘惐山先生遗集》, 清乾隆壬申年新镌证人堂本。)

Nie Fusheng, M. 2002. Studies of Feng Menglong. Shanghai: Xue Lin Press.

Shao Yung, M. 2010. Books of Shao Yung. Beijing: Chung Hua Book Co. (邵庸: 《邵庸 集》，中华书局2010年01月。)

Wang Chi, Z. Books of Wang Chi. Printed in 1588. (王畿: 《龙溪先生全集》, 明万历 十六年绍兴刻本。)

Wang Bi, Z. Books of Wang Bi. Printed in Ch'ing Dynasty. (王譬: 《新镌东崖王先生 遗集》, 明万历刻明崇祯至清嘉庆间递修本。)

Wang Yangming, M. 2012. Books of Wang Yangming. Shanghai: Shanghai Guji Press. (王守仁:《王阳明全集》, 上海古籍出版社 2012 年08 月。)

M. Shangshu. Printed by Juanyüen in Ch'ing Dynasty. (《尚书正义》, 清阮元十三 经注疏本。)

M. Maoshi. Printed by Juanyüen in Ch'ing Dynasty. (《毛诗正义》, 清阮元十三经 注疏本。)

M. The Analects of Confucius. Printed by Juanyüen in Ch'ing Dynasty. (《论语注疏》, 清阮元十三经注疏本。) 